Arch. Tierz., Dummerstorf 48 (2005) 1, 40-49

Faculty of Agriculture, University J.J. Strossmayer, Osijek, Croatia ${ }^{1}$

Institute for Animal Breeding Mariensee, Federal Agricultural Research Center (FAL), Germany²

\author{
GORAN KUSEC $^{1}$, ULRICH BAULAIN ${ }^{2}$, MARTINA HENNING ${ }^{2}$, PETER KÖHLER $^{2}$ and \\ ERHARD KALLWEIT ${ }^{2}$
}

\title{
Fattening, carcass and meat quality traits of hybrid pigs as influenced by MHS genotype and feeding systems
}

\author{
Dedicated to Prof. Dr. Peter Glodek on the occasion of his $70^{\text {th }}$ birthday
}

\begin{abstract}
Within the scope of a growth study fattening, carcass and meat quality traits of MHS gene carriers (Nn) and homozygous negative (NN) castrated male pigs $(n=96)$ kept under two different feeding systems were investigated. The experimental group was intensively fed during the whole fattening period (age 10 to 26 weeks). According to feeding recommendations for barrows, the control group was also fed intensively from $10^{\text {th }}$ to $17^{\text {th }}$ week (growth phase) while feed was restricted from $18^{\text {th }}$ to $26^{\text {th }}$ week (finishing phase). As expected, feeding system affected fattening performance significantly. Intensively fed pigs showed a higher daily feed intake in the finishing phase and in the complete fattening period while no differences could be found in the growth phase. Daily gain was higher in the intensive group than in control during the finishing phase and complete fattening period $(\Delta=285 \mathrm{~g}$ and $\Delta=125 \mathrm{~g}$, resp). Feed conversion ratio was superior in restricted feeding: intensively fed pigs took $230 \mathrm{~g}$ more feed/kg live weight. NN pigs had a higher feed intake and higher daily gain than Nn genotypes. Carcass quality was also influenced by feeding system: pigs of the experimental group which were on average $14.4 \mathrm{~kg}$ heavier than those of the control group had clearly more backfat and percentage of lean was significantly lower. A significant effect of MHS genotype on leanness was not observed. Within intensive feeding system Nn pigs tended to be leaner than NN pigs. In meat quality significant differences between feeding groups were found only for electrical conductivity and for intramuscular fat. For both traits higher values were measured in the experimental group. But meat quality was clearly affected by MHS genotype: in gene carriers significantly lower $\mathrm{pH}_{1}$ values and higher conductivity after $24 \mathrm{~h}$ were found in loin and ham. In tendency, intensively fed NN genotypes had a higher intramuscular fat content than intensively fed Nn pigs.
\end{abstract}

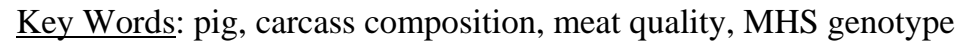

\section{Zusammenfassung}

Titel der Arbeit: Mastleistung, Schlachtkörper- und Fleischqualität von Hybridschweinen in Abhängigkeit vom MHS-Genotyp und der Fütterungsintensität

Im Rahmen einer Wachstumsstudie wurde der Einfluss der Fütterungsintensität auf Mastleistung, Schlachtkörper- und Fleischqualität von MHS heterozygoten (Nn) und homozygot negativen (NN) Börgen ( $\mathrm{n}=96)$ untersucht. Die Versuchsgruppe wurde über die gesamte Mast von der 10. bis zur 26. Lebenswoche intensiv, die Kontrolle gemäß Fütterungsempfehlungen für Kastraten nur in der Anfangsmast von der 10. bis zur 17. Woche intensiv, in der Endmast von der 18. bis zur 26. Woche dagegen restriktiv versorgt. Erwartungsgemäß zeigte die Fütterung einen signifikanten Einfluss auf die Mastleistung. Die intensiv gefütterten Schweine nahmen in der Endmast mehr Futter auf, wogegen in der Anfangsmast noch keine Unterschiede festzustellen waren. Die tägliche Zunahme der intensiv gemästeten Börge war in der Endmast um $285 \mathrm{~g}$ und auf die gesamte Mast bezogen um $125 \mathrm{~g}$ höher als die der Kontrolltiere. In der Futterverwertung erwiesen sich die restriktiv gefütterten Börge als überlegen: Die Intensivgruppe verbrauchte $230 \mathrm{~g}$ mehr Futter pro Kilogramm Zuwachs. NN-Genotypen zeigten in der Anfangsmast eine höhere Futteraufnahme und eine höhere tägliche Zunahme als Nn-Tiere. Die Schlachtkörperqualität wurde ebenfalls durch die Fütterungsvariante beeinflusst; die bei Schlachtung durchschnittlich 14,4 kg schwereren Tiere der Intensivgruppe zeigten eine stärkere Verfettung und einen entsprechend um fünf Prozentpunkte niedrigeren Fleischanteil nach FOM. Ein signifikanter Einfluss des MHS-Genotyps auf 
diesen Merkmalskomplex wurde nicht festgestellt, jedoch waren bei intensiver Fütterung Börge mit dem Genotyp Nn in der Tendenz magerer als NN-Genoytpen. Ein Einfluss der Fütterung auf die Fleischbeschaffenheitsmerkmale konnte nur für die Leitfähigkeit und für intramuskuläres Fett festgestellt werden. Hier wiesen die intensiv versorgten Börge jeweils höhere Messwerte auf, was im Fall der Leitfähigkeit unvorteilhaft ist. Dieser Merkmalskomplex wurde allerdings durch den MHS-Genotyp beeinflusst: Nn-Genotypen zeigten sowohl im Rückenmuskel als auch im Schinken niedrigere $\mathrm{pH}_{1}$-Werte und höhere Leitfähigkeiten als homozygote Tiere. Tendenziell hatten intensiv gefütterte NN- einen höheren intramuskulären Fettgehalt als Nn-Genotypen.

Schlüsselwörter: Schwein, Schlachtkörperzusammensetzung, Fleischbeschaffenheit, MHS-Genotyp

\section{Introduction}

The genetic status of animals and its influence on growth and other production characteristics has been exhaustively investigated in pigs. The MHS stress gene is of special interest in that respect. It was found that reactors to halothane have higher carcass lean content (inter alia AALHUS et al., 1991; POMMIER et al., 1992), but this trait is clearly connected with stress susceptibility resulting in poor meat quality (SATHER et al., 1991; SIMPSON and WEBB, 1989; GÖDEKE et al., 1998; GLODEK et al., 2004). However, differences in fattening traits, carcass and meat quality between MHS gene carriers and homozygous negative pigs are less clear. In some studies authors found that MHS gene carriers grow faster than homozygous negative pigs (LUESCHER et al., 1979); others reported no difference in growth rates between genotypes mentioned (LEACH et al., 1996; MILLER et al., 2000; POMMIER et al., 1992; SATHER et al., 1991; SIMPSON and WEBB, 1989; THALLER et al., 2000) while some authors found higher daily gains in homozygous negative pigs (JENSEN and BARTON-GADE, 1985; WITTMANN et al., 1999). Ambiguous reports about the influence of the MHS gene on feed efficiency ratio can be found in literature. McPHEE et al. (1994) and LEACH et al. (1996) reported an advantage of carriers and reactor pigs over halothane negative pigs, while other studies showed no effect of MHS-genotype on feed efficiency (EIKELENBOOM et al., 1980; JENSEN and BARTON-GADE, 1985; MILLER et al., 2000). LEACH et al. (1996) also argued that if feed efficiency advantage of MHS gene carriers over negative pigs is, at least partially, associated with preferential deposition of lean rather than fat, than it is surprising that more studies have not shown feed efficiency benefits for carrier and reactor pigs.

The objective of this study was to investigate fattening, carcass and meat quality traits of MHS gene carriers and MHS homozygous negative barrows kept under two different feeding regimes. To avoid too much fat in the carcass barrows usually get restricted feed in the finishing phase of fattening. The effects of an intensive feeding applied over the entire fattening period on growth and carcass performance of a frequent market pig should be examined.

\section{Material and methods}

A total of 96 male castrated pigs of the German Hybrid Pig Breeding Programme (BHZP) was investigated in this study. The pigs were 4-way-crosses with a Piétrain $\mathrm{x}$ Hampshire type sire (db-boar 65) and a Large White x Landrace type dam (db-sow), representing a hybrid pig common in the market. All sires were heterozygous stress resistant (MHS genotype $\mathrm{Nn}$ ) whereas all dams were homozygous stress resistant (NN). Owing to the autosomal recessive inheritance of the MHS gene, both NN and 
Nn carriers could be found within a litter. Genetic status of the piglets was determined by DNA test. The pigs derived from 24 litters which were sired by 20 boars. Four litter mates were randomly distributed into four groups regarding the MHS genotypes NN and Nn and two different feeding systems.

The animals were reared in one commercial piglet production farm and arrived at the facilities of the Institute for Animal Breeding Mariensee at the age of 8 weeks. After one week of adaptation they entered the experimental period. The study was carried out in four trials from August 1999 to May 2001.

Animals of the experimental group (intensive) had free access to feed twice a day. They got a feed used for commercial slaughter pigs with an energy content of $13.8 \mathrm{MJ}$ ME per $\mathrm{kg}$ and $17.5 \%$ crude protein in the growth phase and 13.8 MJ ME per kg and $15.0 \%$ crude protein in the finishing phase, respectively. To assure optimum supply of amino acids, lysin, methionin and threonin were added in this group. Energy to lysin ratio was set to 0.6 in the growth and to 0.7 in the finishing phase.

Pigs of the control group were fed according to actual feeding recommendations of BHZP for barrows. From the age of 9 to 17 weeks (approx. 25 to $70 \mathrm{~kg}$ live weight) the pigs were fed ad libitum with 13.8 MJ ME per kg feed and 17.5\% crude protein. Energy intake per day was restricted to 34.0 MJ ME, in the second fattening phase from week 18 to slaughter energy content was 13.0 MJ ME and crude protein 15.0\%.

Excess feed was individually registered daily and feed intake was calculated. Live weights were registered on a weekly basis in order to obtain data for calculation of average daily gain and food conversion. In addition the pigs were scrutinised by magnetic resonance imaging (MRI) to achieve data on body composition.

At the age of 26 weeks the pigs were slaughtered in the experimental slaughter house Mariensee. The following carcass quality traits were recorded: live weight before slaughter, weight of carcass sides, carcass length, dressing percentage, backfat thickness, and lean meat percentage, estimated by the FOM device. Meat quality traits included $\mathrm{pH}$ in $M$. long. dorsi 45 minutes and 24 hours post mortem $\left(\mathrm{pH}_{1}\right.$ and $\left.\mathrm{pH}_{24}\right)$, electrical conductivity measured in $M$. long. dorsi and in M. semimembranosus 24 hours post mortem as well as intramuscular fat content, protein and water content in M. long. dorsi.

The SAS software package 8.10 (SAS, 2000) was applied for analysis of variance. Fixed effects tested for fattening and carcass traits were: trial, genotype, feeding system and genotype*feeding system interaction. For meat quality traits day of slaughter was included into the model instead of trial. For multiple comparison of LSmeans the Tukey-Kramer test was performed. Random effect of litter was also included in the model. Data analysis was performed on the results of 91 animals; five pigs had to be excluded from the experiment because of infections during fattening. Results of simple statistics are given in Table 1 . The whole fattening period is partitioned in two phases: "growth" from 64 to 124 days and "finishing” from 124 to 179 days.

Results and discussion

The influence of trial, feeding regime, MHS-genotype and interaction feeding*genotype on fattening traits is shown in Table 2 and 3. An effect of trial could not be observed except for feed intake in the finishing phase where barrows of the first 
trial ate more than barrows of the second one.

Table 1

Means, standard deviations, minimum and maximum of raw data (Mittelwerte, Standardabweichungen, Minima und Maxima der Rohdaten) $(\mathrm{n}=91)$

\begin{tabular}{|c|c|c|c|c|}
\hline Traits & $\bar{x}$ & $\mathrm{~s}_{\mathrm{x}}$ & $\min$ & $\max$ \\
\hline \multicolumn{5}{|c|}{ fattening traits } \\
\hline live wt. at age of 64 days (kg) & 23.4 & 3.5 & 12.0 & 30.5 \\
\hline live wt. at age of 124 days (kg) & 79.0 & 6.7 & 61.5 & 92.0 \\
\hline live wt. at age of 179 days (kg) & 127.5 & 10.4 & 102.0 & 152.0 \\
\hline feed intake complete $(\mathrm{kg} / \mathrm{d})$ & 2.62 & 0.33 & 1.97 & 3.29 \\
\hline feed intake growth phase $(\mathrm{kg} / \mathrm{d})$ & 2.29 & 0.28 & 1.59 & 2.86 \\
\hline feed intake finishing phase $(\mathrm{kg} / \mathrm{d})$ & 3.18 & 0.64 & 2.55 & 4.54 \\
\hline daily gain complete (g) & 899 & 85 & 724 & 1108 \\
\hline daily gain growth phase (g) & 913 & 76 & 680 & 1098 \\
\hline daily gain finishing phase (g) & 879 & 176 & 618 & 1236 \\
\hline feed conversion (1:) complete & 3.02 & 0.23 & 2.56 & 3.76 \\
\hline feed conversion (1:) growth phase & 2.50 & 0.20 & 2.05 & 3.09 \\
\hline feed conversion (1:) finishing phase & 3.63 & 0.35 & 2.99 & 5.15 \\
\hline \multicolumn{5}{|c|}{ carcass quality traits } \\
\hline weight of left carcass side (kg) & 52.2 & 4.7 & 42.2 & 62.3 \\
\hline carcass length (cm) & 102.6 & 2.8 & 96.0 & 109.0 \\
\hline dressing percentage (\%) & 81.3 & 2.0 & 73.4 & 87.8 \\
\hline backfat 1 (mm) & 37.6 & 6.1 & 24.0 & 49.0 \\
\hline backfat 2 (mm) & 22.9 & 4.4 & 14.0 & 34.0 \\
\hline backfat 3 (mm) & 23.3 & 6.0 & 12.0 & 39.0 \\
\hline FOM, lean percentage (\%) & 50.9 & 4.4 & 40.4 & 58.8 \\
\hline \multicolumn{5}{|c|}{ meat quality traits } \\
\hline pH 45 min, MLD & 6.42 & 0.21 & 5.84 & 6.84 \\
\hline pH 24 h, MLD & 5.42 & 0.07 & 5.26 & 5.63 \\
\hline pH 45 min, MSem & 6.48 & 0.18 & 5.99 & 6.77 \\
\hline pH 24 h, MSem & 5.47 & 0.07 & 5.33 & 5.74 \\
\hline Conductivity 24 h, MLD (mS) & 4.59 & 2.14 & 1.77 & 9.72 \\
\hline Conductivity 24 h, MSem (mS) & 8.29 & 2.94 & 3.22 & 14.67 \\
\hline Chromameter L & 47.30 & 2.24 & 42.85 & 53.47 \\
\hline Intramuscular fat, MLD ( \%) & 1.69 & 0.55 & 0.82 & 3.75 \\
\hline Protein, MLD (\%) & 22.28 & 0.99 & 20.26 & 24.52 \\
\hline Water, MLD (\%) & 74.96 & 0.53 & 73.58 & 76.16 \\
\hline
\end{tabular}

Due to the experimental design, feeding regime affected live weight before slaughter, feed intake, daily gain and feed conversion in the finishing and complete fattening phase significantly. The intensively fed pigs showed an average daily feed intake of $3.75 \mathrm{~kg}$ in the finishing phase while no differences could be found in the growth phase. Intensively fed barrows had a higher daily gain than the controls during the complete fattening phase ( $\Delta=125 \mathrm{~g}$ ), which is mainly caused by the higher gain in the finishing phase ( $\Delta=285 \mathrm{~g}$ ). Consequently, at the age of 179 days a live weight difference of $14.4 \mathrm{~kg}$ between feeding groups occurred. Referring to time, intensively fed pigs achieved a live weight of $115 \mathrm{~kg}$ eleven days earlier than the controls approximately. 
As expected, feed conversion was superior in restricted feeding: ad libitum fed barrows needed $230 \mathrm{~g}$ more feed to gain one kilogram live weight.

Table 2

Significance of fixed effects for fattening traits (Signifikanz der fixen Effekte für Mastleistungsmerkmale)

\begin{tabular}{llccc}
\hline fattening traits & trial & $\begin{array}{c}\text { feeding } \\
\text { system }\end{array}$ & $\begin{array}{c}\text { MHS } \\
\text { genotype }\end{array}$ & $\begin{array}{c}\text { feeding system } \mathrm{x} \\
\text { MHS genotype }\end{array}$ \\
\hline live weight at 64 days & n.s. & n.s. & n.s. & n.s. \\
live weight at 124 days & n.s. & n.s. & $*$ & n.s. \\
live weight at 179 days & n.s. & $* * *$ & n.s. & n.s. \\
feed intake growth phase & n.s. & n.s. & $*$ & n.s. \\
feed intake finishing phase & $*$ & $* * *$ & n.s. & n.s. \\
feed intake total & n.s. & $* * *$ & $*$ & n.s. \\
daily gain growth phase & n.s. & n.s. & $*$ & n.s. \\
daily gain finishing phase & n.s. & $* * *$ & n.s. & n.s. \\
daily gain total & n.s. & $* * *$ & n.s. & n.s. \\
feed conversion growth phase & n.s. & $* * *$ & n.s. & n.s. \\
feed conversion finishing phase & n.s. & $*$ & n.s. & n.s. \\
feed conversion total & n.s. & $* * *$ & & n.s.
\end{tabular}

F test: $* * * \mathrm{p}<0.001 ; * * \mathrm{p}<0.01 ; * \mathrm{p}<0.05 ;$ n.s. $=$ not significant

Table 3

LS means for feeding intensity and MHS genotype in fattening traits (LSQ-Mittelwerte für Fütterungsintensität und MHS-Genotyp bei Mastleistungsmerkmalen) (n=91)

\begin{tabular}{lrr|rrrr}
\hline & \multicolumn{3}{c}{ intensive feeding } & \multicolumn{3}{c}{ standard feeding } \\
fattening traits & $\mathrm{NN}$ & $\mathrm{Nn}$ & $\mathrm{NN}+\mathrm{Nn}$ & $\mathrm{NN}$ & $\mathrm{Nn}$ & $\mathrm{NN}+\mathrm{Nn}$ \\
\hline live wt. at age of 64 days (kg) & 23.9 & 23.0 & 23.4 & 23.7 & 22.8 & 23.2 \\
live wt. at age of 124 days (kg) & 79.7 & 76.2 & 77.9 & 81.1 & 78.9 & 80.0 \\
live wt. at age of 179 days (kg) & 135.8 & 133.4 & 134.6 & 121.5 & 118.7 & 120.1 \\
feed intake growth phase (kg/d) & 2.37 & 2.23 & 2.30 & 2.31 & 2.23 & 2.27 \\
feed intake finishing phase (kg/d) & 3.81 & 3.69 & 3.75 & 2.60 & 2.60 & 2.60 \\
feed intake total (kg/d) & 2.95 & 2.82 & 2.88 & 2.36 & 2.31 & 2.34 \\
daily gain growth phase (g) & 923 & 879 & 901 & 935 & 912 & 924 \\
daily gain finishing phase (g) & 1010 & 1031 & 1020 & 741 & 730 & 735 \\
daily gain total (g) & 967 & 955 & 961 & 845 & 828 & 836 \\
feed conversion growth phase (1:) & 2.56 & 2.52 & 2.54 & 2.47 & 2.45 & 2.46 \\
feed conversion finishing phase (1:) & 3.81 & 3.60 & 3.70 & 3.53 & 3.57 & 3.55 \\
feed conversion total (1: ) & 3.18 & 3.08 & 3.13 & 2.90 & 2.91 & 2.90 \\
\hline
\end{tabular}

MHS-genotype did not affect fattening traits significantly, except for feed intake in the growth and entire fattening phase, and daily gain in the growth phase. NN pigs had a higher feed intake $(\Delta=110 \mathrm{~g})$ and a higher daily gain $(\Delta=33 \mathrm{~g})$ during the growth phase compared to heterozygous negative pigs from both feeding regimes. The results 
of this study are mainly in agreement with findings of SIMPSON and WEBB (1989), SATHER et al. (1991), POMMIER et al. (1992) and MILLER et al. (2000) who reported no difference in average daily gain between the two MHS-genotypes. Contrary to the study presented, LEACH et al. (1996) found a significant difference in feed efficiency in favour of MHS gene carriers indicating that they produce less fat.

The influence of feeding regime, MHS-genotype and corresponding interaction on carcass quality traits is shown in Table 4 and 5. As expected, feeding regime influenced all carcass traits significantly, whereas no effect of MHS-genotype was observed in this study. However, NN-genotypes tended to have more backfat (1.6 to $2.1 \mathrm{~mm}$ ) and less lean (acc. to FOM 2.2\%) than Nn-genotypes when fed intensively.

Table 4

Significance of fixed effects for carcass quality traits (Signifikanz der fixen Effekte für Schlachtleistungsmerkmale)

\begin{tabular}{lcccc}
\hline carcass quality traits & trial & $\begin{array}{c}\text { feeding } \\
\text { system }\end{array}$ & $\begin{array}{c}\text { MHS } \\
\text { genotype }\end{array}$ & $\begin{array}{c}\text { feeding system } \mathrm{x} \\
\text { MHS genotype }\end{array}$ \\
\hline live weight before slaughter & n.s. & $* * *$ & n.s. & n.s. \\
weight of left carcass side & n.s. & $* * *$ & n.s. & n.s. \\
carcass length & n.s. & $* *$ & n.s. & n.s. \\
dressing percentage & $*$ & $* * *$ & n.s. & n.s. \\
backfat 1 & $* *$ & $* * *$ & n.s. & n.s. \\
backfat 2 & $*$ & $* * *$ & n.s. & n.s. \\
backfat 3 & n.s. & $* * *$ & n.s. & $*$ \\
FOM, lean percentage & n.s. & $* * *$ & n.s. & .
\end{tabular}

F-test: ${ }^{* * *} \mathrm{p}<0.001 ; * * \mathrm{p}<0.01 ;{ }^{*} \mathrm{p}<0.05 ;$ n.s. $=$ not significant

Table 5

LS means for feeding system and MHS genotype in carcass quality traits (LSQ-Mittelwerte für Fütterungssystem und MHS-Genotyp bei Schlachtleistungsmerkmalen) (n=91)

\begin{tabular}{lrr|rrrrr}
\hline carcass quality traits & \multicolumn{3}{c}{ intensive feeding } & \multicolumn{3}{c}{ standard feeding } \\
& $\mathrm{NN}$ & $\mathrm{Nn}$ & $\mathrm{NN}+\mathrm{Nn}$ & $\mathrm{NN}$ & $\mathrm{Nn}$ & $\mathrm{NN}+\mathrm{Nn}$ \\
\hline live weight before slaughter (kg) & 135.79 & 133.38 & 134.58 & 121.58 & 118.68 & 120.13 \\
weight of left carcass side (kg) & 55.88 & 55.31 & 55.60 & 49.18 & 48.14 & 48.66 \\
carcass length (cm) & 103.5 & 103.1 & 103.3 & 102.7 & 100.8 & 101.8 \\
dressing percentage (\%) & 81.85 & 82.58 & 82.21 & 80.22 & 80.55 & 80.35 \\
backfat 1 (mm) & 42.21 & 40.44 & 41.33 & 33.63 & 33.91 & 33.77 \\
backfat 2 (mm) & 26.67 & 24.62 & 25.64 & 19.91 & 20.26 & 20.08 \\
backfat 3 (mm) & 28.96 & 27.42 & 28.19 & 18.49 & 18.33 & 18.41 \\
FOM, lean percentage (\%) & 47.22 & 49.36 & 48.29 & 53.85 & 53.81 & 53.83 \\
\hline
\end{tabular}

This is also in contrast to the results of LEACH et al. (1996) who found clear differences in carcass weights and dressing percentages between the NN and Nn genotypes. An increased dressing percentage of MHS-gene carrier pigs was also observed by POMMIER et al. (1992). On the other hand, SATHER et al. (1991) and MILLER et al. (2000) did not find differences between the two MHS-genotypes in 
dressing percentage which is supported by this study. Classification of carcasses according to the EUROP scheme, as presented in Table 6, led to statistically significant differences between feeding regimes and MHS-genotypes, too. But it must be considered for this and the other carcass composition traits discussed above, that the barrows from the experimental group had a slaughter weight which does not meet the normal market requirements. From the genotype comparison it is evident that 12 from $47 \mathrm{NN}$ pigs were classified as “E”.

Table 6

Influence of feeding system and MHS genotype on EUROP carcass classification (Einfluss der Fütterungsintensität und des MHS-Genotyps auf die EUROP-Klassifizierung)

\begin{tabular}{ccccc}
\hline & \multicolumn{2}{c}{ feeding system } & \multicolumn{2}{c}{ MHS genotype } \\
classification & intensive & standard & NN & Nn \\
\hline $\mathrm{E}$ & 3 & 18 & 12 & 9 \\
$\mathrm{U}$ & 15 & 24 & 16 & 9 \\
$\mathrm{R}$ & 17 & 3 & 11 & 3 \\
$\mathrm{O}$ & 11 & 0 & 8 & 0 \\
$\mathrm{P}$ & 0 & 0 & 0 & \\
\hline$* * \mathrm{p}<0.01 ; * \mathrm{p}<0.05 ;$ & \multicolumn{2}{c}{$\chi^{2}=33.58^{* *}$}
\end{tabular}

Table 7

$\underline{\text { Significance of fixed effects for meat quality traits (Signifikanz der fixen Effekte auf Fleischqualitätsmerkmale) }}$

\begin{tabular}{lcccc}
\hline meat quality traits & $\begin{array}{c}\text { day of } \\
\text { slaughter }\end{array}$ & $\begin{array}{c}\text { feeding } \\
\text { system }\end{array}$ & $\begin{array}{c}\text { MHS } \\
\text { genotype }\end{array}$ & $\begin{array}{c}\text { feeding system } \mathrm{x} \\
\text { MHS genotype }\end{array}$ \\
\hline $\mathrm{pH}_{1}$ in M. long. dorsi & n.s. & n.s. & $* * *$ & n.s. \\
$\mathrm{pH}_{24}$ in M. long. dorsi & n.s. & n.s & n.s. & n.s. \\
$\mathrm{pH}_{1}$ in ham & n.s. & n.s. & $* * *$ & n.s. \\
$\mathrm{pH}_{24}$ in ham & n.s. & n.s. & n.s. & n.s. \\
Conductivity 24 in M.l.d. & n.s. & $* * *$ & $* * *$ & n.s. \\
Conductivity & n.s. \\
Chromameter L & $*$ & $* * *$ & $* * *$ & n.s. \\
Intramuscular fat, $\%$ & n.s. & n.s. & n.s. & $*$ \\
Protein, $\%$ & n.s. & $* * *$ & n.s. & n.s. \\
Water, $\%$ & n.s. & n.s. & n.s. & n.s.
\end{tabular}

The influence of feeding regime, MHS-genotype and interaction on meat quality traits is shown in Table 7 and 8 . It is obvious that meat quality was very good in all traits. Significant differences between feeding groups were found for electrical conductivity in $M$. long. dorsi and in ham although there were no differences in water content. It is known that meat fluids contain charged compounds which enhance electric current conductivity, thus meat characterised by higher water percentage should be expected to be less resistant to a current and vice versa. As expected clear differences between the two feedings systems were found in intramuscular fat content: intensively fed pigs 
had $0.4 \%$ more intramuscular fat than those from the control group. Concerning the MHS-genotype significantly lower $\mathrm{pH}$ values 45 minutes after slaughter in $M$. long. dorsi and ham and a higher conductivity in M. long. dorsi and ham 24 hours post mortem were detected. It was shown by many authors that MHS-genotype affects meat quality of pigs. In our study distinct genoytpe differences were observed in all meat quality indicators investigated with the exception of $\mathrm{pH}_{24}$ in $M$. long. dorsi and in $M$. semimembranosus (ham) as previously shown by LEACH et al. (1996) and MILLER et al. (2000). MHS-genotype did also not influence Chromameter L values, intramuscular fat, protein and water content of the meat. A significantly higher quantity of intramuscular fat influenced by feeding system and MHS genotype interaction suggests that homozygous negative pigs tend to deposit more fat than MHS gene carriers when fed intensively. This is in agreement with the lower percentage of lean in this group (Table 3).

Table 8

LS means for feeding intensity and MHS genotype in meat quality traits (LSQ-Mittelwerte für Fütterungsintensität und MHS-Genotyp bei Fleischqualitätsmerkmalen) (n=91)

\begin{tabular}{lrrrrrrr}
\hline meat quality traits & \multicolumn{3}{c}{ intensive feeding } & \multicolumn{3}{c}{ standard feeding } \\
& $\mathrm{NN}$ & $\mathrm{Nn}$ & $\mathrm{NN}+\mathrm{Nn}$ & $\mathrm{NN}$ & $\mathrm{Nn}$ & $\mathrm{NN}+\mathrm{Nn}$ \\
\hline $\mathrm{pH}_{1}$ in M. long. dorsi & 6.54 & 6.28 & 6.41 & 6.53 & 6.34 & 6.43 \\
$\mathrm{pH}_{24}$ in M. long. dorsi & 5.43 & 5.41 & 5.42 & 5.42 & 5.42 & 5.42 \\
$\mathrm{pH}_{1}$ in M. semim. & 6.55 & 6.39 & 6.47 & 6.56 & 6.43 & 6.49 \\
$\mathrm{pH}_{24}$ in M. semim. & 5.47 & 5.47 & 5.47 & 5.47 & 5.46 & 5.46 \\
$\mathrm{Conductivity}_{24}$ in M.l.d. (mS) & 3.74 & 6.80 & 5.27 & 2.93 & 5.11 & 4.01 \\
Conductivity 24 in M.sem. (mS) & 7.72 & 10.29 & 9.01 & 6.65 & 8.64 & 7.64 \\
Chromameter L in M.l.d. & 46.54 & 48.21 & 47.37 & 47.32 & 47.29 & 47.26 \\
Intramuscular fat (\%) & 2.06 & 1.73 & 1.90 & 1.48 & 1.47 & 1.48 \\
Protein (\%) & 21.95 & 22.36 & 22.15 & 22.35 & 22.43 & 22.39 \\
Water (\%) & 74.81 & 74.92 & 74.87 & 75.10 & 75.03 & 75.06 \\
\hline
\end{tabular}

\section{Conclusions}

The data presented are part of a growth study, where muscle and fat depostion of castrated male hybrid pigs with different MHS genotype was analysed under intensive and restricted feeding. Testing scheme was age related, i.e. all group comparisons were made at the same age, but not at the same body weight. Consequently, fattening and carcass quality traits were clearly affected by feeding system. Likewise distinct influence of the MHS-genoytpe on these traits could not be found, only during the growth phase $\left(10^{\text {th }}\right.$ to $17^{\text {th }}$ week) feed intake and daily gain of homozygous negative (NN) pigs was higher, in particular when fed intensively. An effect of the MHSgenotype on carcass composition traits could not be observed in the study, but NNgenotypes tended to have more fat and less lean when not fed according to the feeding recommendations for barrows.

It is obvious that all pigs slaughtered had very good meat quality. But MHS-genotype showed a significant influence on $\mathrm{pH}_{1}$ in $M$. long. dorsi and ham, as well as electrical 
conductivity in $M$. long. dorsi and ham measured after 24 hours in favour of MHS negative pigs $(\mathrm{NN})$.

Due to a more favourable daily feed intake and daily gain during the growth phase and a superior meat quality MHS homozgous negative pigs (NN) provide an advantage over gene carriers. Since carcass traits of the pigs investigated do not seem to be influenced by genotype, there is no reason to use gene carriers in pork production.

\section{Acknowledgement}

The authors wish to thank Dr. Wilke Griep from "Züchtungszentrale Deutsches Hybridschwein GmbH, Lüneburg” for his excellent support, the Institute of Animal Breeding and Genetics, University of Goettingen, for the MHS gene test and Degussa AG, Feed Additives, for supplementation with amino acids and feed analyses.

\section{References}

AALHUS, J. L.; JONES, W. M.; ROBERTSON, W. M.; TONG, A. K. W.; SATHER, A. P.: Growth characteristics and carcass composition of pigs with known genotypes for stress susceptibility over a weight range of 70 to $120 \mathrm{~kg}$. Anim. Prod. 52 (1991), 347-353

EIKELENBOOM, G.; MINKEMA, D.; VAN ELDIK, P.; SYBESMA, W.: Performance of Dutch Landrace pigs with different genotypes for the halothane-induced malignant hyperthermia syndrome. Livestock Production Science 7 (1980), 317-324

GLODEK, P.; KRATZ, R.; SCHULZ, E.; FLACHOWSKY, G.:

Der Einfluss unterschiedlicher Vaterrassen in praxisüblichen Schweinekreuzungen auf deren Ansatzleistung, Schlachtkörperzusammensetzung sowie Fleisch- und Fettbeschaffenheit. Arch. Tierz., Dummerstorf 47 (2004), 1, 59-74

GÖDEKE, K.; GLODEK, P.; MEYER, J.N.; BRANDT, H.:

Der Einfluss des MHS-Streßgens auf die Fleischleistung und Fleischbeschaffenheit der Nachkommen von Pietrain- und (Pietrain * Hampshire)-Kreuzungsebern. Arch. Tierz., Dummerstorf 41 (1998) 5, 433446

JENSEN, P.; BARTON-GADE, P. A.:

Performance and carcass characteristics of pigs with known genotypes for halothane susceptibility. In "Stress susceptibility and meat quality in pigs. Proceedings of the Commission on Animal Management and Health and Commission of Pig Production" (EAAP, ed.), Vol. 33, 1985, pp. 80, Pudoc, Wageningen, The Netherlands

LEACH, L. M.; ELLIS, M.; SUTTON, D. S.; MCKEITH, F. K.; WILSON, E. R.:

The growth performance, carcass characteristics, and meat quality of halothane carrier and negative pigs. J. Anim. Sci. 74 (1996), 934-943

LUESCHER, U.; SCHNEIDER, A.; JUCKER, H.:

Genetics of halothane-sensitivity and change of performance, carcass and meat quality traits induced by selection against halothane sensitivity. In "Proc. 30th Annual Meeting of the EAAP", 1979, Harrogate, England

McPHEE, C. P.; DANIELS, L. J.; KRAMER, H. L.; MACBETH, G. M.; NOBLE, J. W.:

The effects of selection for lean growth and the halothane allele on growth performance and mortality of pigs in tropical environment. Livestock Production Science 38 (1994), 117-123

MILLER, K. D.; ELLIS, M.; MCKEITH, F. K.; WILSON, E. R.: Influence of sire line and halothane genotype on growth performance, carcass characteristics and meat quality in pigs. Can. J. Anim. Sci. 80 (2000), 319-327

POMMIER, S. A. ; HOUDE, A. ; ROUSSEAU, F.; SAVOIE, Y.:

The effect of the malignant hyperthermia genotype as determined by a restriction endonuclease assay on carcass characteristics of commercial crossbred pigs. Can. J. Anim. Sci. 72 (1992), 973-976

SATHER, A. P.; MURRAY, A. C.; ZAWADSKI, S. M.; JOHNSON, P.:

The effect of the halothane gene on pork production and meat quality of pigs reared under commercial conditions. Can. J. Anim. Sci. 71 (1991), 959-967

SIMPSON, S. P.; WEBB, A. J:

Growth and carcass performances of British Landrace pigs heterozygous at the halothane locus. Anim. Prod. 49 (1989), 503-509 
THALLER, G.; DEMPFLE, L.; SCHLECHT, A.; WIEDEMANN, S.; EICHINGER, H.; FRIES, R.:

Effects of the MHS locus on growth, carcass and meat quality traits in $F_{2}$ crosses between Mangalitza and Pietrain breeds. Arch. Tierz., Dummerstorf 43 (2000) 3, 263-275

WITTMANN, W.; GÖTZ, K.-U.; PESCHKE, W.; LINDNER, J.-P.; HAUSER, M.:

Einfluß des MHS-Genotyps auf die Mast- und Schlachtleistung von Pietrainschweinen und PI x DLMastendprodukten in der Stationsprüfung. Arch. Tierz., Dummerstorf 42 (1999) 2, 139-147

Received: 2004-10-25

Accepted: 2004-12-14

Author's addresses

Dr. GORAN KUSEC

Faculty of Agriculture

University J.J. Strossmayer

P.O. Box 719

31000 Osijek

Croatia

E-mail: kusec@pfos.hr

Dr. ULRICH BAULAIN, Dr. MARTINA HENNING,

Prof. Dr. ERHARD KALLWEIT, Dr. PETER KÖHLER

Institut für Tierzucht Mariensee der Bundesforschungsanstalt

für Landwirtschaft (FAL)

Höltystr. 10

D-31535 Neustadt

Germany

E-mail: ulrich.baulain@fal.de, martina.henning@fal.de, peter.koehler@fal.de, e.kallweit@freenet.de 